\title{
Relationship between Malignancy Types and Toxoplasmosis Incidence in Malignancy Patients with Chemotherapy at Dr. M. Djamil Hospital
}

\author{
Selfi Renita Rusjdi ${ }^{1}$, Emilia Sasqia Puteri ${ }^{2}$ and Almurdi ${ }^{3}$ \\ ${ }^{1}$ Parasitology Laboratory, Faculty of Medicine, Andalas University, Padang 25138, Indonesia \\ ${ }^{2}$ Faculty of Medicine, Andalas University, Padang 25138, Indonesia \\ *Corresponding author
}

\section{A B S T R A C T}

\begin{abstract}
Toxoplasma gondii is a protozoan that causes toxoplasmosis. Immunological status is an important factor in the course of the Toxoplasma gondii parasitic infection. This disease is often the cause of opportunistic infections that can be life-threatening in immunocompromised individuals. In immunocompromised malignancies, the risk of infection is higher than in immunocompetent individuals. The risk of infection increases when malignancy patients with chemotherapy treatment which makes the patient's immune status decrease.To determine the relationship of the type of malignancy with the incidence of toxoplasmosis in malignancy patients with chemotherapy at RSUP Dr. M. Djamil Padang.This study was an observational analytic study with a cross-sectional design by using consecutive techniques. The research started from November2019 until January 2020 in the Chemotherapy Unit and Clinical Pathology Laboratory Dr. M. Djamil Padang with a total sample of fifty-four people. The research instrument used was the EnzymeLinked Immunosorbent Assay (ELISA) test for IgG and IgM antibodies in the blood serum of toxoplasmosis patients. The incidence of toxoplasmosis in malignancy patients with chemotherapy at RSUP Dr. M. Djamil Padang as much as 74.1 percent. According to the division of types of malignancy, toxoplasmosis was found in hematological malignancies as much as 86.7 percent and in solid malignancies as much as 69.2 percent. The significance value obtained was 0.302.The type of malignancy was not significantly related to the incidence of toxoplasmosis in malignancy patients with chemotherapy because it did not meet the $\mathrm{p}$-value $<0.05$.
\end{abstract}

\section{Keywords}

Toxoplasmosis, Malignancy types

Article Info

Accepted:

22 June 2020

Available Online:

10 July 2020

\section{Introduction}

Toxoplasma gondii is an obligate intracellular organism which causes the zoonotic disease of toxoplasmosis. This disease could be transmitted through consumption of uncooked or half-cooked food containing tissue cysts or water contaminated by oocysts. Transmission of this parasite could also occur through contact with infected animals, congenital transmission, blood transfusion, and organ transplantation. ${ }^{1}$ Toxoplasmosis infects more than a third of the world population with prevalence rates which vary between $30 \%$ $60 \%{ }^{2}$ 
Immunological status of an individual is an important factor which affects the infection course of the Toxoplasma gondii parasite. Toxoplasma gondii infection could be the cause of opportunistic infections which could be life-threatening in immunocompromised patients. $^{3}$

In malignancy patients, occurs an increase of Toxoplasma gondii parasite infection risk compared to immunocompetent individuals. This has been shown in results of study conducted by Liu et al., in year 2019. ${ }^{4}$ An increase of infection risk is caused by patients with chemotherapy, whether as a single or combined treatment, due to the decrease of the patient's immune. ${ }^{5}$

Chemotherapeutic treatments work by killing malignant cells which actively divide. ${ }^{5}$ However, those medications could not differentiate malignant cells from normal cells which also actively divide such as leukocytes in bone marrow. This causes destruction of normal cells and kills blood cells produced by the bone marrow, therefore the patient's blood cells will decrease, including the leukocytes. Patients with leukopenia will be more susceptible to infections. ${ }^{6}$

In immunocompetent individuals, infections commonly occur without symptoms and could be healed on itself. Immunocompetent individuals have macrophages and $T$ lymphocytes which could limit the spread of tachyzoites in different organs. However, vice versa, immunocompromised patients will be fatally affected if infected by Toxoplasma gondii. This is caused by reactivation of latent stadium.

In latent stadium, Toxoplasma gondii will stay and live in the form of cysts within the host's tissues, especially in immunologically inactive tissues such as the central nervous system (CNS). ${ }^{7}$ Throughout the latent stadium, humoral and cellular immune system, especially $\mathrm{T}$ lymphocytes and macrophages, play an important role in controlling the spread of tissue cysts. Reactivation of tissue cyst in CNS could cause cerebral toxoplasmosis which could lead to death. ${ }^{8}$

Development of tachyzoite stadium causes infection of surrounding cells which leads to necrosis. Infected patients could experience pneumonia, retinochoroiditis, myocarditis, up to manifestations in the brain such as encephalitis and cerebral toxoplasmosis. ${ }^{9}$

Toxoplasmosis could be marked as a main cause of morbidity in malignancy patients with chemotherapy with predominance in hematological malignancies. This is due to the destruction of normal hematopoiesis in hematological malignancy. Neoplasm in myeloid and lymphoid tissues causes destruction of the hematopoiesis process, causing an accumulation of immune suppression against immune cells, therefore many patients with such malignancies experience a disruption of cellular immunity and an increased risk of Toxoplasma gondii infection. $^{10,11}$

Studies show that patients with hematological malignancies have a higher IgG seropositivity compared to solid malignancies, with a prevalence rate of $40 \%$ and $26.7 \%$. Toxoplasma gondii IgM seropositivity also shows a higher rate in hematological malignancies $(5.8 \%)$ compared to solid malignancies $(3.3 \%){ }^{5}$

Based on the aforementioned background, the researcher is interested to determine the relationship between malignancy types and toxoplasmosis incidence in malignancy patients with chemotherapy at RSUP Dr. M. Djamil Padang. 


\section{Materials and Methods}

This study was an observational analytical study with cross-sectional design using consecutive sampling technique. Population of this study was observed once and variables were directly measured in the examination. Independent variable was malignancy types and dependent variable was toxoplasmosis incidence. Subjects of this study were malignancy patients who came to undergo chemotherapy during November 2019January 2020.

Subjects of this study were a total of 54 patients which has been calculated according to the Stanley Lames show formula. Selected subjects were malignancy patients with chemotherapy which met inclusion and exclusion criteria. Subject inclusion criteria: malignancy patients with chemotherapy at RSUP Dr. M. Djamil Padang and consenting to be study subjects by signing a provided informed consent. Subject exclusion criteria: malignancy patients which have only once undergone chemotherapy.

The conducted examination was EnzymeLinked Immunosorbent Assay (ELISA). The examination used blood specimens taken directly by staffs of chemotherapy unit of RSUP Dr. M. Djamil Padang under the supervision of a surgical oncologist and an internist of the hematology-oncology department. Instrument of this examination used ELISA kits produced by PT. Enseval.

Data were analyzed statistically based on variables which were measured with a computerized system of univariate and bivariate analysis. Univariate analysis was conducted to see the frequency distribution of each independent and dependent variable. Bivariate analysis was conducted to analyze the relationship between independent variable and dependent variable. Relationship between those two variables was analyzed with ChiSquare test and was considered significant if $\mathrm{p}$ value $<0.05$. This study has passed ethical review with the reference number of 362/KEPK/2019.

\section{Results and Discussion}

In this study, from 54subjects specimens which have been examined, incidence of toxoplasmosis was found in 40 positive cases with a percentage of $74.1 \%$. A higher incidence of toxoplasmosis in patients of hematological malignancies compared to solid malignancies, with percentages of $86.7 \%$ and $69.2 \%$.

Obtained results were in accordance with other studies, including a study by Ali et al., in 2019 in Egypt, which stated that 80 out of $120(66.7 \%)$ samples of blood specimen from malignancy patients undergoing chemotherapy were positively containing anti-Toxoplasma gondii $\operatorname{IgG}$ antibodies. ${ }^{5}$ Results of another study by Alim et al., in 2018 showed that out of 100 malignancy patients undergoing chemotherapy, 60 of them $(60 \%)$ were found to be positively containing anti-Toxoplasma gondiiIgG antibodies. ${ }^{12}$ Furthermore, study by Bajnok et $a l$., in 2018 showed that out of 72 malignancy patients as study subjects, all (100\%) of them were found to be positive of anti-Toxoplasma gondii antibodies.

In 2010, study by Baiomy in Egypt including blood and fecal examination towards parasites showed results of incidence of opportunistic infections caused by parasites in 30\% of immunocompromised patients and 10\% of immunocompetent individuals. These results were obtained from immunocompromised patients and immunocompetent individuals divided into four groups, including three groups of immunocompromised patients and one group of immunocompetent individuals. 
Prevalence found in this study showed highest rate of parasitosis in malignancy patients. ${ }^{13}$ Dysfunction of $\mathrm{T}$ cells in immunocompromised patients, including malignancy patients undergoing chemotherapy, causes said patients to have a high risk Toxoplasma gondii infection. ${ }^{14}$ Based on study by Ariawati in 2007, decrease of leukocytes was found in patients of Acute Lymphoblastic Leukemia (ALL) after administration of chemotherapy regimen. Results of the study showed the lowest level of leukocyte in induction phase at $500 / \mu \mathrm{L}$, this decrease occurs after administration of the first and second chemotherapy regimens. ${ }^{15}$ Total of leukocytes, mainly granulocytes (ANC) $\leq 1000 / \mu \mathrm{L}$, shows a low count of neutrophils and a weak immune system. The lower the total of ANC, the higher the risk of infection. ${ }^{16}$

In this study, there is no significant relationship between malignancy types with toxoplasmosis incidence in patients undergoing chemotherapy. In cross-test table, one cell had an expected count of less than 5 . Therefore, an alternative of Chi-Square test was used, namely Fisher's Exact Test. Results of statistical test using Fisher's Exact Test showed $p$ value $=0.302(p>0.05)$.

Toxoplasmosis in individuals depends on the individual's immune system. Individuals with disruptions in the immune system will experience an increased risk of Toxoplasma gondii infection. ${ }^{17}$ Natural immune response which occurs immediately after the entry of Toxoplasma gondii is production of IL-12 by dendritic cells followed by neutrophils, monocytes, and macrophages. Several studies show that low levels of IL-12 will cause an increase of susceptibility towards toxoplasmosis. ${ }^{18}$ Other studies show that the role of neutrophils is also involved due to decrease of neutrophil production which could cause decrease of IL-12 production. $^{18}$ Neutrophil is an alternative source of IL-12 production during Toxoplasma gondii infection. Decrease of IL-12 could cause an increase of parasite replication. Neutrophil also has a role as an effector cell to kill parasites through phagocytosis mechanism to inhibit parasite growth. ${ }^{19}$

A high risk of infection in malignancy patients could be caused by changes of the immune function of an individual. Such changes in function could be caused by the malignancy itself, the treatments received, and inadequate nutrition. ${ }^{20}$ Therefore, study by Abdel et al., in 2015 in Cairo showed higher results in solid malignancy compared to hematological malignancy, with percentages of $24 \%$ and $12 \%$. Their study explained that there is no impact of malignancy type towards prevalence of toxoplasmosis. $^{21}$

Other than the patient's immune function, this unassociated result is also caused by variations of exposure of risk factors of Toxoplasma gondii infection in each individuals. This also depends on the patient's conditions, including home environment, social and economical factors, hygiene, sanitation, and eating habit of said individuals. $^{22}$

Table.1 Frequency distribution of toxoplasmosis incidence in malignancy patients with chemotherapy at RSUP Dr. M. Djamil Padang

\begin{tabular}{|l|c|c|}
\hline Toxoplasmosis incidence & f & $\%$ \\
\hline Positive toxoplasmosis & 40 & 74,1 \\
Negative toxoplasmosis & 14 & 25.9 \\
\hline Total & 54 & 100 \\
\hline
\end{tabular}


Table.2 Frequency distribution of toxoplasmosis incidence based on malignancy types

\begin{tabular}{|ll|c|c|c|c|c|}
\hline Malignancy Classification & \multicolumn{2}{|c|}{ Sample } & \multicolumn{2}{|c|}{ Positive } & $\%$ \\
\hline Hematologic & Total & (f) & Total & $(\mathbf{f})$ & \\
& Lymphoma & 10 & 15 & 9 & 13 & 86,7 \\
& Leukemia & 3 & & 3 & & \\
Multiple Myeloma & 2 & & 1 & & \\
& & & & & & \\
& Breasts & 16 & 39 & 13 & 27 & 69,2 \\
& Gynecological & 8 & & 3 & & \\
& Colon & 5 & & 5 & & \\
Rectal & 3 & & 2 & & \\
Bone & 2 & & 1 & & \\
& Soft-tissue sarcoma & 2 & & 2 & & \\
& Lungs & 1 & & 0 & & \\
& Nasopharyngeal & 1 & & 1 & & \\
& Pancreas & 1 & & 0 & & \\
\hline
\end{tabular}

Table 3. Relationship between malignancy types and toxoplasmosis incidence in patients with chemotherapy

\begin{tabular}{|l|c|c|c|c|c|}
\hline \multirow{2}{*}{$\begin{array}{l}\text { Toxoplasmosis } \\
\text { Incidence }\end{array}$} & \multicolumn{4}{|c|}{ Malignancy Type } & \multirow{2}{*}{$\boldsymbol{p}$} \\
\cline { 2 - 6 } & Hematologic & \multicolumn{2}{|c|}{ Solid } & value \\
\cline { 2 - 5 } & f & $\%$ & f & $\%$ & \\
\hline Toxoplasma (+) & 13 & 86.7 & 27 & 69.2 & 0.302 \\
\hline Toxoplasma (-) & 2 & 13.3 & 12 & 30.8 & \\
\hline Total & 15 & 100 & 39 & 100 & \\
\hline
\end{tabular}

Based on the results of this study, it was concluded that the incidence rate of toxoplasmosis in malignancy patients with chemotherapy at RSUP Dr. M. Djamil was 74.1\%. Based on malignancy types, toxoplasmosis was more commonly found in patients with hematological malignancies. However, each infected individuals depend on their own immune system and risk exposure, therefore there was no relationship between malignancy types and toxoplasmosis incidence.

\section{References}

Abdel MR, Wassef R, Rizk E, Sabry H, Tadros N, Boghdady A. Toxoplasmosis an Overlooked Disease: Seroprevalence in Cancer Patients. Asian Pacific Jorunal of Cancer Prevention : APJCP. 2018; 19(7): 1987-91.

Abdoli A, Barati M, Dalimi A, Pirestani M,Shokouh SJH. Toxoplasmosis Among Patients with Immunocompromising Conditions: A Snapshot. Journal of Archives in Military Medicine. 2016; 4(4): e41832.

Ali MI,Wahab WMAE, Hamdy DA, Hassan A. Toxoplasma gondiiinCancer Patients Receiving Chemotherapy: Seroprevalence and Interferon Gamma Level. Journal of Parasitic Diseases: Official Organ of the Indian Society for Parasitology. 2019; 43(3): 464-471.

Alim M, Özçelik S, Özpınar N. Seroprevalence of Toxoplasma gondii in 
Patients Receiving Cancer Treatment. Cumhuriyet Medical Journal. 2018; 40(1): 19-24.

American Cancer Society. Low White Blood Cell (Neutrophil) Count and the Risk of Infection. The American Cancer Society. 2017.

American Cancer Society. Poor Nutrition Can Affect Infection Risk in People with Cancer. The American Cancer Society. 2015.

http://www.cancer.org/treatment/treatm

ents-and-side-effects/physical-side-

effects/low-blood-

counts/infections/infections-in-people-

with-cancer/low-wbc-and-weak-

immune-system.html - Diakses Februari 2020.

Anvari D, Sharif M, Sarvi S, Aghayan SA, Gholami S, Pagheh AS, et al., Seroprevalence of Toxoplasma gondii Infection in Cancer Patients: A Systematic Review and Meta-Analysis. Microbial Pathogenesis. 2019; 129: 3042.

Ariawati K, Windiastuti E, Gatot D. Toksisitas Kemoterapi Leukemia Limfoblastik Akut pada Fase Induksi \& Profilaksis Susunan Saraf Pusat dengan Metotreksat 1 Gram. Sari Pediatri. 2007; 9(4): 252-8.

Bachireddy P, Burkhardt UE, Rajasagi M, Wu CJ. Hematologic Malignancies: at the Forefront of Immunotherapeutic Innovation. Nature Reviews, Cancer. 2015; 15(4): 201-215.

Baiomy AM, Mohamed KA, Ghannam MA, Shahat SA, Al-Saadawy AS. Opportunistic Parasitic Infections Among Immunocompromised Egyptian Patients. Journal of the EgyptSociety of Parasitology. 2010; 40(3): 797-808.

Bajnok J, Tarabulsi M, Carlin H, Bown K, Southworth T, Dungwa J, et al., High Frequency of Infection of Lung Cancer Patients with the Parasite Toxoplasma gondii. ERJ Open Research. 2019; 5(2): 00143-2018.

Bhadra R, Gigley JP, Weiss LM, Khan IA. Control of Toxoplasma Reactivation by Rescue of Dysfunctional CD8+ T-cell Response via PD-1-PDL-1 Blockade. Proceedings of the National Academy of Sciences of the United States of America. 2011; 108(22): 9196-9201.

Cong W, Liu GH, Meng QF, Dong W, Qin SY, Zhang FK, et al., Toxoplasma gondii Infection in Cancer Patients: Prevalence, Risk Factors, Genotypes and relationship with Clinical Diagnosis.Cancer Letters. 2015; 359(2): 307-13.

Dupont CD, Christian DA, Hunter CA. Immune Response and Immunopathology During Toxoplasmosis. Seminars in Immunopathology. 2012; 34(6): 793813.

Foroutan-Rad M, Majidiani H, Dalvand S, Daryani A, Kooti W, Saki J, et al., Toxoplasmosis in Blood Donors: A Systematic Review and Meta-Analysis. Transfusion Medicine Reviews. 2016; 30(3): 116-122.

Goldszmid RS, Dzutsev A, Trinchieri G. Host Immune Response to Infection and Cancer: Unexpected Commonalities. Cell Host\&Microbe. 2014; 15(3): 295305.

Halonen SK, Weiss LM. Toxoplasmosis. Handbook of Clinical Neurology. 2013; 114: 125-145.

Iddawela D, Vithana SMP, Ratnayake C. Seroprevalence of Toxoplasmosis and Risk Factors of Toxoplasma gondii Infection Among Pregnant Women in Sri Lanka: A Cross Sectional Study. BMC Public Health. 2017;17(1):930.

Li Y. T-Cell Immune Suppression in Patients with Hematologic Malignancies: Clinical Implications. International Journal of HematologicOncology. 
2014;3(4):289-297.

Liu L, Wang P, Xu J, Xia CM. Increased Risk of Toxoplasma gondiiInfection in Cancer Patients: A Meta-Analysis of Current Evidence Based on CaseControl Study. Acta Tropica. 2019; 192: $30-40$.

Sasai M, Pradipta A, Yamamoto M. Host Immune Responses to Toxoplasma gondii. International Immunology.
2018; 30(3): 113-19.

Tosh KW, Mittereder L, Bonne-Annee S, Hieny S, Nutman TB, Singer SM, et al., The IL-12 Response of Primary Human Dendritic Cells and Monocytes to Toxoplasma gondii is Stimulated by Phagocytosis of Live Parasites Rather Than Host Cell Invasion. Journal of Immunology (Baltimore, Md.: 1950). 2016; 196(1): 345-56.

\section{How to cite this article:}

Selfi Renita Rusjdi, Emilia Sasqia Puteri and Almurdi. 2020. Relationship between Malignancy Types and Toxoplasmosis Incidence in Malignancy Patients with Chemotherapy at Dr. M. Djamil Hospital. Int.J.Curr.Microbiol.App.Sci. 9(07): 2581-2587.

doi: https://doi.org/10.20546/ijcmas.2020.907.304 